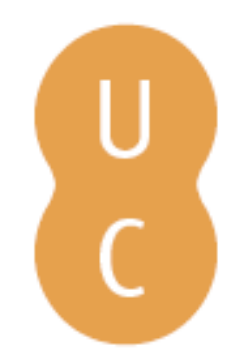

\title{
pommalina
}

\section{"Carta dos direitos fundamentais da União Europeia": uma visão desde a História}

\author{
Autor(es): $\quad$ Baltazar, Isabel
}

Publicado por: Imprensa da Universidade de Coimbra

URL

persistente: URI:http://hdl.handle.net/10316.2/47303

DOI: $\quad$ DOI:https://doi.org/10.14195/978-989-26-1849-4_12

Accessed : $\quad$ 26-Apr-2023 16:12:43

A navegação consulta e descarregamento dos títulos inseridos nas Bibliotecas Digitais UC Digitalis, UC Pombalina e UC Impactum, pressupõem a aceitação plena e sem reservas dos Termos e Condições de Uso destas Bibliotecas Digitais, disponíveis em https://digitalis.uc.pt/pt-pt/termos.

Conforme exposto nos referidos Termos e Condições de Uso, o descarregamento de títulos de acesso restrito requer uma licença válida de autorização devendo o utilizador aceder ao(s) documento(s) a partir de um endereço de IP da instituição detentora da supramencionada licença.

Ao utilizador é apenas permitido o descarregamento para uso pessoal, pelo que o emprego do(s) título(s) descarregado(s) para outro fim, designadamente comercial, carece de autorização do respetivo autor ou editor da obra.

Na medida em que todas as obras da UC Digitalis se encontram protegidas pelo Código do Direito de Autor e Direitos Conexos e demais legislação aplicável, toda a cópia, parcial ou total, deste documento, nos casos em que é legalmente admitida, deverá conter ou fazer-se acompanhar por este aviso.

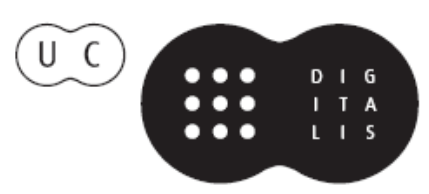


Euro-Atlântico:

Espaço de Diálogos

Isabel Maria Freitas Valente

Iranilson Buriti de Oliveira

(Coord)

\section{VISÕES \\ INTERDISCIPLINARES \\ DA EUROPA \\ E DO MUNDO:}

uma experiência de convergência

disciplinar em homenagem a

Maria Manuela Tavares Ribeiro

Alexandra Aragão

Isabel Maria Freitas Valente

Dulce Lopes

(org.)

Editora da Universidade Federal de Campina Grande

Imprensa da Universidade de Coimbra

2019 


\section{"CARTA DOS DIREITOS FUNDAMENTAIS DA UNIÃO EUROPEIA”, UMA VISÃO DESDE A HISTÓRIA}

Isabel Baltazar

É muito interessante a abordagem interdisciplinar deste texto sobre a Carta dos direitos fundamentais da União Europeia de Isabel Valente e Dulce Lopes. Partindo de uma memória histórica, as autoras mostram como este projecto de cidadania se foi transformando num projecto político envolvendo os vinte e oito países, dando origem à Carta dos Direitos Fundamentais da União Europeia.

A sua análise da Carta dos Direitos Fundamentais da União Europeia é feita à luz do Tratado de Lisboa, porquanto a Carta dos Direitos Fundamentais se tornou juridicamente vinculativa com o Tratado de Lisboa, ainda que na sequência de uma proclamação política datada já de 7 de Dezembro de 2000, no Conselho Europeu de Nice ${ }^{1}$.

As autoras conseguem articular os aspectos jurídicos da Carta, referindo a sua estrutura e função, com a sua aplicabilidade da vida dos cidadãos e da necessidade de forjar uma cidadania activa que os envolva, para que o projecto europeu se fortaleça. De forma muito bem conseguida, vão fazendo um contraponto entre os Direitos Fundamentais e como estes direitos se relacionam com o dia -a -dia dos cidadãos europeus, nessa necessária interdisciplinaridade que concilie os direitos com as práticas de cidadania, a forma jurídica com a vivência desses direitos, e a necessidade de informar os cidadãos europeus dos seus direitos e deveres. É fundamental que a União Europeia saiba comunicar bem para que os cidadãos tenham, de facto, uma consciência de cidadania europeia.

Este texto é muito original porque consegue conciliar os Direitos

1 Todavia, essa proclamação em 2000 constituiu tão-só um compromisso político, sem efeitos jurídicos vinculativos. Aquando dos trabalhos da Convenção Europeia e da Conferência Intergovernamental de 2003-2004, a Carta foi adaptada - nomeadamente no que diz respeito às suas disposições gerais - com o intuito de a tornar juridicamente vinculativa.f 
Fundamentais da Carta com a interdisciplinaridade necessária para que esses direitos sejam conhecidos e postos em prática através de uma educação para uma cidadania europeia. Por isso, o Direito, a Política, a História e a Educação, são disciplinas que se complementam para o objectivo essencial de que os Direitos Fundamentais sejam interiorizados e vividos pelos cidadãos.

Por outro lado, fica a ideia de que não basta o compromisso dos Estados-Membros em fazer cumprir a Carta dos Direitos Fundamentais, se antes não houver uma informação sobre os mesmos e, primeiro que tudo, uma formação para esta cidadania. Vale a pena ler a sua convicção de que

"estamos certas que, só com o esclarecimento destes, a consciência clara do que está em causa em cada momento, dos compromissos que os Estados-membros têm de fazer, do caminho que se quer seguir e do valor intrínseco, se pode construir uma União Europeia forte e mais próxima, capaz de mobilizar não apenas os seus cidadãos (ainda que sobretudo estes) mas também todos os demais atores sociais, económicos e políticos, provenientes dos mais diversos quadrantes e ramos do saber"2.

Embora a dimensão da cidadania europeia esteja inscrita, há mais de vinte anos, no Tratado de Maastricht (1992), onde pode ler-se: “ É instituída a Cidadania da União" e, a seguir, "É cidadão da União qualquer pessoa que tenha a nacionalidade de um Estado-membro", na realidade trata-se de um mecanismo formal de afirmação de um direito não assumido e, por isso, não vivido pelos cidadãos dos 28 estados membros, mas, como salientam as autoras, temos de passar da teoria à prática.

É fundamental o significado do Preâmbulo, onde se pode ler que "os povos da Europa, estabelecendo entre si uma união cada vez mais estreita, decidiram partilhar um futuro de paz, assente em valores comuns"3. É na consciência do seu património espiritual e moral que

2 Valente, Isabel e Lopes, Dulce, Carta dos direitos fundamentais da União Europeia: uma perspectiva interdisciplinar, p.1.

3 Preâmbulo da Carta dos Direitos Fundamentais da União Europeia. 
a União se baseia nos valores indivisíveis e universais da dignidade do ser humano, da liberdade, da igualdade e da solidariedade; nos princípios da democracia e do Estado de direito. A cidadania da União significa criar um espaço de liberdade, de segurança e de justiça, onde o ser humano está no centro. A preservação e o desenvolvimento destes valores comuns, o respeito pela diversidade das culturas e das tradições dos povos da Europa, bem como da identidade nacional dos EstadosMembros numa comunidade unida na diversidade. 